\title{
CHANGES IN MYOCARDIAL OXYGEN CONSUMPTION, EFFICIENCY AND HAEMODYNAMICS WHEN SYSTEMIC PRESSURE IS INCREASED DURING MORPHINE AND ADDED HALOTHANE ANAESTHESIA IN DOGS
}

\author{
Philip L. Wilkinson, John V. Tyberg, John R. Moyers and anne E. White
}

\section{ABstract}

\begin{abstract}
Depression of left ventricular function by the combination of hatothane anaesthesia and increased ventricular afterload may undesirably reduce stroke volume and increase myocardial oxygen consumption by increasing ventricular wall stress.

To investigate this possibility we studied six dogs instrumented to measure systemic and left ventricular pressures, ascending aortic and left anterior descending coronary artery flows and external left ventricular diameters. We sampled arterial and coronary sinus blood gases and axygen contents.

During morphine anaesthesia $\left(4 \mathrm{mg} \cdot \mathrm{kg}^{-1}\right.$ intravenously with hourly supplements of $\left.0.1 \mathrm{mg} \cdot \mathrm{kg}^{-1}\right)$ and during added halothane anaesthesia (1.5 per cent end tidal) we measured systemic pressure, heart rate, stroke volume, stroke work, cardiac output, left ventricular end diastolic pressure and diameter and myocardial oxygen consumption. After infusing phenylephrine $(0.02 \mathrm{mg} / \mathrm{ml})$ to increase systolic pressure to $23.28 \mathrm{kPa}$ (175 torr) we repeated measurements in both groups.

We found that added halothane depressed systemic pressures ( 52 per cent), stroke volume ( 30 per cent), and myocardial oxygen consumption ( 46 per cent) compared to morphine alone. When afterioad was increased with phenylephrine, stroke volume (20 per cent), cardiac output ( 25 per cent) and myocardial efficiency ( 47 per cent) were further depressed during added halothane anaesthesia compared to control halothane anaesthesia. Left ventricular end diastolic diameter ( 5 per cent) and pressure ( 320 per cent) were significantly increased by added afterload, compared to the control added halothane state. Conversely, increased afterload produced few changes during morphinc anacsthesia alone. However, at comparable systemic pressures, myocardial oxygen consumption was similar during both anacsthetic states. We conclude that during added halothane anaesthesia increased afterload decreases stroke volume and myocardial efficiency. Cardiac output is reduced without increased myocardial oxygen consumption compared to morphine anaesthesia at comparable afterload states. In patients with already compromised cardiac output, further depression of stroke volume by increased ventricular afterload during halothane anaesthesia may be deleterious.
\end{abstract}

IN AWAKE MAN, Ross and Braunwald showed that increased left-ventricular afterload does not decrease left-ventricular stroke volume, provided ventricular contractility is not depressed. ${ }^{1}$ In 18 patients, they raised systemic blood pressure with angiotensin to mean pressures of

Philip L. Wilkinson, M.B., B.S., Assistant Professor in Residence, Department of Anaesthesia. John $V$. Tyberg. M.D., Ph.D., Assistant Professor in Residence, Departments of Medicine. Physiology and the Cardiovascular Research Institute. John R. Moyers, M.D., Assistant Professor, Department of Anaesthesia. Anne E. White, M.S., Staff Research Assistant, Department of Anaesthesia.

From the Departments of Anaesthesia and Cardiology, University of California, San Francisco.

Correspondence to: Philip L. Wilkinson, M.B., B.S. Department of Anaesthesia, 436-S, University of California, San Francisco, San Francisco, California 94143 , U.S.A.

Supported by: Anesthesia Research Center Grant. NIGMS GM 15571-11, a Program Project Grant HL06285, and Grant-in-Aid from A.H.A. with funds contributed in part by the California Affiliate.

Canad Anaesth. Soc. J., vol. 27, no. 3, May 1980
$100-110$ torr, $(13.3-14.63 \mathrm{kPa})$, and constructed ventricular function curves. Stroke volume was maintained only in the absence of myocardial dysfunction. In an animal study, Sonnenblick and Downing ${ }^{2}$ similarly report no change in leftventricular stroke volume over a mean systemic pressure range of $75-120$ torr $(9.98-15.96 \mathrm{kPa})$.

Halothane depresses ventricular contractile performance in dogs and primates, ${ }^{3}$ and stroke volume and cardiac output at clinical concentrations in man. ${ }^{4}$ Despite this depression of pump function, evidence suggests that cardiac output is adequate for a reduced peripheral oxygen requirement. ${ }^{5}$ However, if ventricular afterload is increased during halothane anaesthesia, the depressed ventricular function produced by halothane may cause further depression of stroke volume similar to the reduced stroke volume seen by Ross and Braunwald in patients with depressed ventricular performance.' This depression of stroke volume might render cardiac output inadequate for peripheral tissue require- 
time-related effects of halothane. Instrumentation took an average of three hours and measurements a further four hours. In those animals where morphine measurements followed halothane measurements, we waited for end-tidal halothane concentrations to be less than $0.1 \mathrm{per}$ cent before proceeding. To increase ventricular afterload, a phenylephrine infusion $(0.02 \mathrm{mg} / \mathrm{ml})$ was administered until systolic blood pressure rose to 175 torr $(23.28 \mathrm{kPa})$. After a stable 5 minute period at this pressure, measurements were repeated during each anaesthetic state. Where halothane measurements were made first, we waited until end-tidal halothane concentrations were less than 0.1 per cent before making measurements during morphine anaesthesia. There was no apparent difference between morphine measurements made before or after halothane ( $P>0.05$, unpaired " $t$ " test).

From the data obtained, we calculated oxygen consumption as the product of coronary blood flow and the aortic-to-coronary sinus oxygen content difference. It is assumed that coronary sinus oxygen content represents that of the effluent from the region perfused by the left anterior descending coronary artery and the calculated $\mathrm{mVO}_{2}$ represents the oxygen consumption of the region perfused by that artery. This measured parameter is proportional to total $\mathrm{mVO}_{2}$, assuming flow in the left anterior descending coronary artery varies as the total flow. We calculated cardiac output as the product of stroke volume and heart rate and myocardial efficiency as the ratio of minute work (stroke work $x$ heart rate) to $m \dot{\mathrm{V}}_{2}$. External left ventricular enddiastolic diameter (LVEDD) was calculated as the product of the speed of sound in tissue $(1.55 \mathrm{~mm} / \mu \mathrm{sec})$ and the transit time between crystals at end-diastole.

Data were analyzed by repeated measures analysis of variance for the four conditions of the experiment. ${ }^{7} \mathrm{~F}$ ratios for variance during the four experimental states were calculated and Fisher's protected " $t$ " testing conducted where $F$ ratios were significant. In this manner, significant differences between the four states were detected. Analysis was conducted using an Exidy microcomputer with $16 \mathrm{~K}$ memory programmed in BASIC

\section{RESULTS}

Results are summarized in Table I, and their significance is summarized in Table II.

\section{Comparisons between morphine and added halothane anaesthesia}

Under control conditions, adding halothane 1.5 per cent to morphine anaesthesia decreased mean blood pressure, stroke volume and $\mathrm{mV}_{2}$ significantly and increased heart rate, but did not significantly change LVEDD or pressure, cardiac output or cardiac efficiency. When ventricular afterload was increased by raising systemic pressure with phenylephrine, added halothane anaesthesia depressed stroke volume, stroke work, cardiac output and cardiac efficiency significantly, while LVEDP increased significantly. Mean blood pressure, heart rate, $\mathrm{mVO}_{2}$, and LVEDD were not significantly different.

\section{Effects of increased ventricular afterload}

During morphine anaesthesia the increase in peripheral resistance produced by phenylephrine did not significantly change any variable with the exception of mean blood pressure and $\mathrm{mVO}_{2}$.

During added halothane anaesthesia, phenylephrine increased peripheral resistance, increased systemic pressure, LVEDD, LVEDP, and $\mathrm{mVO}_{2}$ significantly, while decreasing myocardial efficiency, stroke volume and cardiac output. Stroke work did not change significantly with increased afterload during added halothane anaesthesia, since stroke volume decreased as systemic pressure increased.

Figure 2 shows no difference between LVEDP under control morphine and added halothane conditions. However, over a range of mean pressures, added halothane anaesthesia is associated with higher LVEDP at any given mean systemic pressure. Figure 3 shows cardiac output decreasing with increased systemic pressure during added halothane, but not during morphine anaesthesia. This decreased cardiac output causes decreased myocardial efficiency during added halothane anaesthesia, but efficiency remains unchanged during morphine anaesthesia (Figure 4). However, added halothane depresses left-ventricular stroke work significantly when compared to morphine anaesthesia at all levels of aortic pressure (Figure 5). Interestingly, Figure 6 demonstrates that $\mathrm{mV}_{2}$ is similar for both morphine and added halothane anaesthesia provided that mean pressures are the same, despite their different effects upon the determinants of $\mathrm{n}_{1} \mathrm{~V}_{2}$. Figure 7 shows that the relationship between stroke work and LVEDP is depressed during halothane anaesthesia. While not a true ven- 
ments. In addition, halothane-induced increases in ventricular volume and diameter might increase oxygen consumption, since wall tension is increased by increased size. This increased oxygen cost of decreased stroke work might be deleterious.

Increased ventricular afterload occurs commonly from the increased systemic pressure seen during vascular surgical procedures. Examples are supra-renal and infra-renal aortic crossclamping, causing increased systemic pressures, and vasopressor infusions to maintain cercbral perfusion during carotid artery surgery. Halothane anaesthesia for these procedures might be associated with depressed myocardial performance, increased myocardial oxygen consumption $\left(\mathrm{mVO}_{2}\right)$ and inadequate perfusion of peripheral tissues.

In seven dogs, we have examined myocardial performance and haemodynamics during morphine anaesthesia and added halothane anaesthesia after increasing aortic pressure with an infusion of phenylephrine. We found that the addition of halothane depresses contractile performance significantly and reduces myocardial efficiency without increasing $\mathrm{mV}_{2}$. During added halothane anaesthesia stroke volume is decreased by increased peripheral resistance and large increases in filling pressures occur.

\section{METHODS}

In seven mongrel dogs $(20.1 \pm 1.0 \mathrm{~kg})$, we administered basal anaesthesia with morphine sulphate $4 \mathrm{mg} \cdot \mathrm{kg}^{-1}$ after induction with intravenous thiopentone $10 \mathrm{mg} \cdot \mathrm{kg}^{-1}$. We supplemented anaesthesia with morphine sulphate $0.1 \mathrm{mg} \cdot \mathrm{kg}^{-1}$ at hourly intervals. The tracheae were intubated and the lungs were ventilated with a Harvard animal respirator. A succinylcholine infusion ( $2 \mathrm{mg} / \mathrm{ml}$ concentration) was administered at a rate just sufficient to prevent spontaneous respiration. Blood gases were maintained with $\mathrm{Pa}_{\mathrm{CO}_{2}}$ between 4.66 and $5.99 \mathrm{kPa}$ (35 and 45 torr) and $\mathrm{Pa}_{\mathrm{O}_{2}}$ greater than $13.3 \mathrm{kPa}$ ( 100 torr). Calculated base deficits greater than five were corrected by administration of sodium bicarbonate. Figure 1 shows the instrumentation employed.

After attaching electrocardiographic limb leads, we measured central aortic pressure using a catheter inserted through a femoral artery cutdown. We inserted a catheter tip transducer (Millar) into the left ventricle through a carotid artery cut-down. Through a left lateral thoracotomy incision we attached calibrated flow

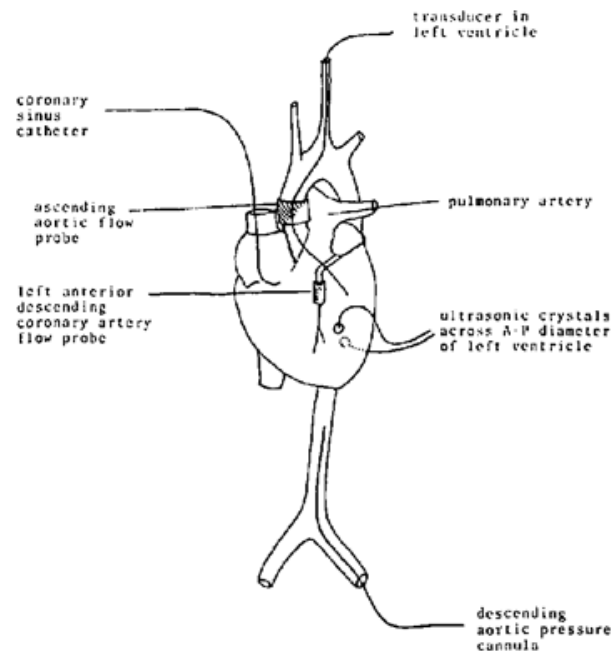

Figure I Schematic representation of instrumentation used

probes (Carolina Medical Electronics, King, NC) around the ascending aorta and left anterior descending coronary artery. We attached ultrasonic dimensioning crystals across the external anteroposterior diameter of the left ventricle. Through an external jugular cut-down, a coronary sinus catheter was inserted into the coronary sinus.

The catheter tip transducer was calibrated by comparison with a mercury manometer before insertion. Zero coronary flow was obtained by acclusion of the vessel beyond the probe. Ultrasonic crystal separation was calibrated by comparison with an internal reference source. Using an analog computer (Mini AC, EAl, West Long Branch, NJ), we obtained stroke volume by integrating the aortic flow signal. Stroke work was processed similarly as the integral of the product of left ventricular pressure and aortic flow.

We measured left ventricular end-diastolic pressure (LVEDP). End-tidal halothane concentrations were measured using an ultraviolet halothane meter (Cavitron) attached to a sampling tube inserted through the tracheal tube. Blood gases were measured (Model BGM2, The London Company, Cleveland, $\mathrm{OH}$ ) and calibrated before each determination. Oxygen content was determined using a modified Klingenmeier method. ${ }^{6}$

Control morphine measurements were made randomly before or after control halothane $(1.5$ per cent ET) measurements to minimize the 
TABLE 1

SUMMARY OF RESULTS (7 dogs)

\begin{tabular}{|c|c|c|c|c|}
\hline \multirow[b]{2}{*}{ Variable } & \multicolumn{2}{|c|}{ Control } & \multicolumn{2}{|c|}{ Increased Afterload } \\
\hline & Morphine & + Halothane & Morphine & + Halothane \\
\hline Mean blood pressure $\mathrm{kPa}$ (torr) & $\begin{array}{r}X \pm \text { S.D. } \\
15.39 \pm 2.00 \\
(115.7 \pm 15.1)\end{array}$ & $\begin{array}{r}X \pm S . D \\
7.50 \pm 0.64 \\
(56.4 \pm 4.8)\end{array}$ & $\begin{array}{r}X \pm S . D . \\
19.54 \pm 1.48 \\
(146.9 \pm 11.1)\end{array}$ & $\begin{array}{r}X \pm S . D \\
18.05 \pm 0.89 \\
(135.7 \pm 6.7)\end{array}$ \\
\hline Heart rate (beat $/ \mathrm{min}$ ) & $102.4 \pm 17.1$ & $119 \pm 11.0$ & $97.3 \pm 12.9$ & $109.1 \pm 16.6$ \\
\hline Stroke volume $(\mathrm{ml})$ & $15.1 \pm 5.1$ & $10.6 \pm 2.3$ & $15.6 \pm 4.3$ & $8.5 \pm 1.8$ \\
\hline Stroke work $(g \cdot m)$ & $18.1 \pm 7.4$ & $6.4 \pm 1.6$ & $21.5 \pm 7.1$ & $9.7 \pm 2.6$ \\
\hline Left ventricular end diastolic & $1.54 \pm 0.52$ & $1.41 \pm 0.81$ & $2.34 \pm 1.28$ & $4.39+1.16$ \\
\hline Pressure kPa (torr) & $(11.6 \pm 3.9)$ & $(10.6 \pm 6.1)$ & $(17.6 \pm 9.6)$ & $(33.0 \pm 8.7)$ \\
\hline Cardiac output (litres/min) & $1.5 \pm 0.45$ & $1.2 \pm 0.21$ & $1.7 \pm 0.50$ & $0.90 \pm 0.15$ \\
\hline $\begin{array}{l}\text { Myocardial } \mathrm{O}_{2} \text { consumption } \\
(\mathrm{ml} / \mathrm{min})\end{array}$ & $276 \pm 74$ & $150 \pm 20$ & $353 \pm 66$ & $314 \pm 69$ \\
\hline Efficiency (percent) & $6.7 \pm 2.1$ & $5.5 \pm 1.6$ & $6.7 \pm 2.9$ & $3.5 \pm 1.0$ \\
\hline $\begin{array}{l}\text { Left ventricular end diastolic } \\
\text { Diameter }(\mathrm{mm})\end{array}$ & $47.7 \pm 2.5$ & $48.0 \pm 1.2$ & $49.4 \pm 2.5$ & $50.4 \pm 2.2$ \\
\hline Base deficit (before correction) & $10.1 \pm 2.1$ & $10.0 \pm 3.0$ & $8.7 \pm 1.3$ & $9.9 \pm 2.1$ \\
\hline
\end{tabular}

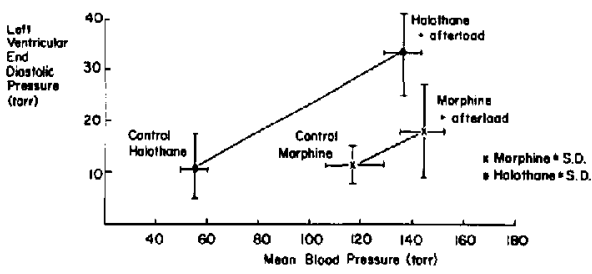

Figure 2 In 7 dogs, left ventricular end diastolic pressure increases with increased mean blood pressure. At any given mean blood pressure, halothane is associated with greater end diastolic pressures.

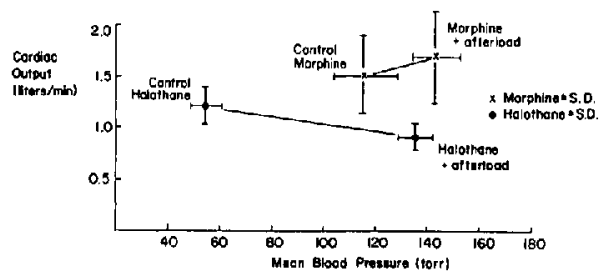

FIgure 3 Cardiac output is significantly depressed by increased mean blood pressure in 7 dogs, during halothane anaesthesia.

tricular function curve, since end-diastolic pressure was increased by changing systemic pressures, this figure suggests that ventricular function is depressed by the addition of halothane.

\section{Discussion}

Morphine is associated with less cardiovascular depression than halothane, when systemic pressures are increased by raising peripheral re-

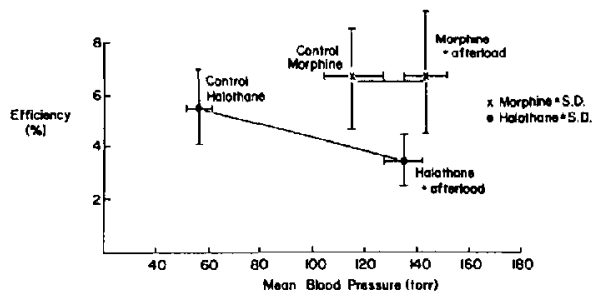

FIGURE 4 Myocardial efficiency is decreased when mean blood pressure is increased during halothane anaesthesia. Control halothane efficiency is not significantly different $(p>0.05)$ from either morphine state.

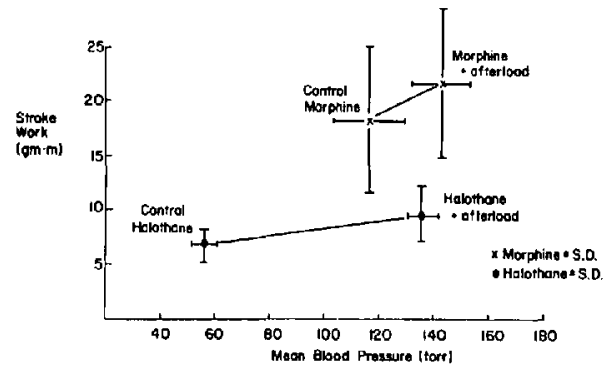

Figure 5 in 7 dogs, stroke work is depressed during halothane anaesthesia compared to morphine anaesthesia. Stroke work does not significantly increase $(p>0.05)$ during either anaesthetic state when mean blood pressure is increased.

sistance with phenylephrine. During added halothane anaesthesia, the increased afterload associated with raised peripheral resistance depresses stroke volume and cardiac output 
TABLE II

Significance Matrices for Repeated Measures analysis of Variance and Fisher's PROTECTED " $t$ " Testing $\left(*=p<.05,{ }^{* *}=p<.01\right)$

\begin{tabular}{|c|c|c|c|c|}
\hline Parameter & Measurement period & $\begin{array}{c}\text { Control } \\
\mathbf{H}\end{array}$ & $\begin{array}{c}\text { MS + } \\
\text { Afterload }\end{array}$ & $\begin{array}{c}\mathbf{H}+ \\
\text { Afterload }\end{array}$ \\
\hline \multirow[t]{3}{*}{ Mean blood pressure } & Control MS & ** & ** & ** \\
\hline & Control H & & ** & ** \\
\hline & MS + Afterload & & & - \\
\hline \multirow[t]{3}{*}{ Heart rate } & Control MS & * & - & - \\
\hline & Control H & & * & - \\
\hline & MS + Afterload & & & - \\
\hline \multirow[t]{3}{*}{ Stroke volume } & Control MS & $* *$ & - & ** \\
\hline & Control H & & ** & - \\
\hline & MS + Afterload & & & $* *$ \\
\hline \multirow[t]{3}{*}{ Stroke work } & Control MS & ** & - & ** \\
\hline & Control H & & ** & - \\
\hline & MS + Afterload & & & ** \\
\hline \multirow{3}{*}{$\begin{array}{l}\text { Left ventricular } \\
\text { end diastolic pressure }\end{array}$} & Control MS & - & - & ** \\
\hline & Control H & & - & ** \\
\hline & MS + Afterload & & & *** \\
\hline \multirow{3}{*}{$\begin{array}{l}\text { Left ventricular } \\
\text { end diastolic diameter }\end{array}$} & Control MS & - & - & - \\
\hline & Control $\mathrm{H}$ & & - & * \\
\hline & MS + Afterload & & & - \\
\hline \multirow{3}{*}{ Myocardial $\mathrm{O}_{2}$ consumption } & Control MS & ${ }^{* *}$ & $* *$ & - \\
\hline & Control $\mathrm{H}$ & & $* *$ & $* *$ \\
\hline & MS + Afterload & & & $\overline{-}$ \\
\hline \multirow{3}{*}{ Cardiac output } & Control MS & - & - & ** \\
\hline & Control $\mathrm{H}$ & & ** & *** \\
\hline & $\mathrm{MS}+$ Afterload & & & *** \\
\hline \multirow{3}{*}{ Efficiency } & Control MS & - & - & ** \\
\hline & Control $\mathrm{H}$ & & - & ** \\
\hline & MS + Afterload & & & ** \\
\hline
\end{tabular}

Measurement period Control $\mathrm{MS}=$ control morphine, Control $\mathrm{H}=$ control halothane, MS + Afterload $=$ morphine + afterload, $\mathbf{H}+$ Afterload $=$ halothanc + afterload.

The table is used in the following manner. To determine the difference between mean blood pressure at measurement periods "Control MS" and " $H+$ Afterload", enter the table at the row marked "Control MS". The two asterisks at the intersection with column "H + Aftcrload" indicate that measurement periods "Control MS" and "H + Afterload" are significantly different $p<.01$.

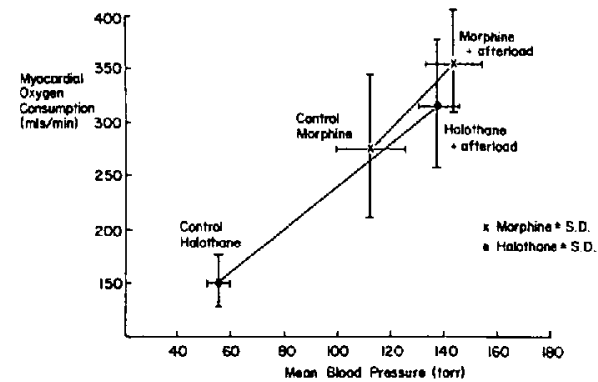

Figure 6 In 7 dogs, myocardial oxygen consumption is depressed by halothane when compared to mor. phine. However, al comparable mean blood pressures, myocardial oxygen consumption is similar during both anaesthetic states.

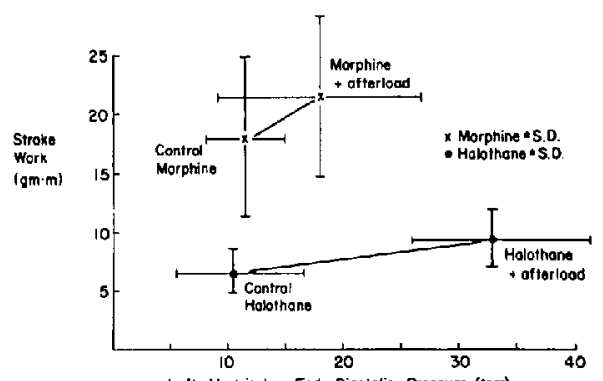

Left Ventricular Ena Diastolic Prassure (torr)

FIGURE 7 In 7 dogs, the relationship between stroke work and left ventricular end diastolic pressure is depressed during halothane anaesthesia, suggesting decreased contractile performance. 
significantly. While the oxygen cost of generating this reduced cardiac output is not increased by added halothane, it is not proportionally rcduced, and myocardial efficiency is decreased. When compared to morphine anaesthesia, stroke volume, cardiac output and stroke work during added halothane anaesthesia are depressed significantly during both control and increased systemic pressure states.

Ross and Braunwald have shown that stroke volume is maintained when afterload increases in awake man, provided there is no associated depression of cardiac contractile performance.' In their study, pressures were raised by angiotensin infusions, and systolic pressure did not exceed 170 torr $(22.61 \mathrm{kPa})$ in the majority of cases. Similar results and conclusions were made in an animal study by Sonnenblick, ${ }^{2}$ and increased ventricular volume (preload) in response to increased mean systemic pressure is probably the mechanism responsible for the maintenance of stroke volume in these circumstances. ${ }^{8,9}$ Increased systemic pressure only increased external ventricular diameter by approximately $5 \mathrm{per}$ cent in our study. However, when diameter is related to volume by the cubic law, this change produces a 15 per cent increase in ventricular volume.

Similar changes occur when ventricular volume is directly increased by changing preload, rather than afterload. The magnitude of the Frank-Starling effect, or increase in stroke work and stroke volume in response to increased preload, is dependent upon the inotropic state of the left ventricle; depressed ventricular function means that a given increase in preload will produce a smaller increase in strokc volume and stroke work. Figure 6 shows that depression of ventricular function produced by halothane, resulting in decreased stroke volume and cardiac output in our experiment. While due to changing afterload, this depression is similar to that observed by others when preload is changed during halothane anaesthesia.

In any study involving extensive cardiovascular instrumentation, one wonders what role the instrumentation itself plays in the results. Gross surgical trauma, blood loss, and increased catechol secretion might invalidate the results observed. In addition, these factors might producc an unstable preparation with timedependent effects. While these effects are hard to exclude, we do not believe that they were significant in this study. No dog died before com- pletion of the experiment, and the normal ventricular function apparent in dogs anaesthetized with morphine would suggest little effect of instrumentation alone. To minimize timedependent effects, the order of halothane and morphine administration was randomized and, since each dog served as its own control, the effects of instrumentation are minimized. However, the base deficit present in all four measurement states (Table I) indicates some degree of generalized metabolic acidosis, perhaps as a response to the stress of instrumentation.

When halothane is added to morphine anaesthesia, stroke volume, cardiac output, and stroke work are depressed significantly at both afterload states. This depression must be interpreted relative to total body oxygen and metabolic demands. If these demands are reduced to the same degree as stroke volume and cardiac output, adequate perfusion of the body has still occurred. The only measure of the adequacy of total body perfusion in this study is base excess. Table 1 shows no significant difference between calculated base deficits at any of the four measurement intervals. However, this is a crude measure, not reflecting individual organ requirements. Mixed venous oxygen content has also been used to assess the adequacy of total body oxygen supply and demand, ${ }^{5}$ but also does not reflect the adequacy of individual organ bed perfusion. Some organs may be under-supplied and others over-supplied, yet the mixed venous oxygen content remains within normal limits.

When aortic pressure is increased to comparable values during both anaesthetic conditions, $\mathrm{mVO}_{2}$ associated with halothane does not exceed that measured during morphine anaesthesia (Figure 5), despite a greater systolic wall stress, since LVEDP and LVEDD were significantly elevated during halothane anaesthesia. While this increase in wall stress might increase $\mathrm{mV}_{2}$, the decreased $\mathrm{mV}_{2}$ due to reduced left-ventricular contractile performance may have offset this, resulting in similar $m \dot{V}_{2}$ for both anaesthetics at any given mean systemic pressure.

It is interesting to speculate on the quantitative effects of concurrent changes in contractility and diastolic volume upon wall stress and $\mathrm{mV}_{2}$. Graham $^{12}$ demonstrated that changes in both contractile performance and wall tension had quantitatively similar effects upon $\mathrm{mV}_{\mathrm{z}}$. Vatner ${ }^{3}$ showed that two per cent halothane anaesthesia produced 68 per cent depression of contractile performance in dogs and primates. On the basis 
of these two observations, one may speculate that halothane (end-tidal 1.5 per cent) might produce a 50 per cent reduction in $\mathrm{mVO}_{2}$ in the absence of any change in wall tension or heart rate. Conversely, in our study, we saw a small 5.2 per cent increase in LVEDD and hence leftventricular wall stress, by the law of Laplace. Since $\mathrm{mVO}_{2}$ is not different between the two anaesthetic conditions at high systemic pressures, it is possible that the reduction in contractility was at least comparable to the increase in wall stress. However, when ventricular volume increases 300 to 400 per cent in the presence of cardiomyopathies or valvular heart disease, ${ }^{13}$ wall stress due to increased heart size will have a significant effect on $\mathrm{mVO}_{2}$, and perhaps additional increases due to anaesthetic agents will have significant effects.

Myocardial oxygen supply may be compromised by the high LVEDP during the combination of added halothane anaesthesia and increased systemic pressure. Buckburg and associates have shown that proximal aortic constriction resulting in elevated ventricular enddiastolic pressure caused significant reduction in subendocardial blood flow. ${ }^{10} \mathrm{We}$ did not measure subendocardial flow and cannot comment on this point.

While halothane added to morphine anaesthesia does not significantly decrease myocardial efficiency at normal aortic pressures, increased systemic pressures during halothane anaesthesia do depress myocardial efficiency significantly as compared to control halothane and to both morphine anaesthetic states. The myocardium requires additional oxygen to generate a given cardiac output during the combination of increased afterload and added halothane anaesthesia. In the presence of reduced myocardial oxygen delivery produced by anaemia or ischaemic heart disease, these changes might be deleterious. Myocardial oxygen consumption in this study includes only oxygen consumed by the major portion of the left ventricle, since right coronary and left circumflex coronary flow was not measured. However, in the absence of increased afterload, the values obtained for calculated efficiency are in accordance with those measured by others for halothane anaesthesia. ${ }^{11}$

Insofar as our results can be extrapolated to man, they suggest that increased systemic pressures during halothane anaesthesia depress stroke volume and cardiac output and increase LVEDP and LVEDD. The increase in LVEDD and the associated increase in left-ventricular wall stress, while theoretically tending to increase $\mathrm{mV}_{2}$, are offset by the oxygen sparing effect of decreased contractile performance. Myocardial oxygen consumption is unchanged, but myocardial efficiency is decreased, since cardiac output is depressed. In addition, the increased LVEDP may threaten subendocardial perfusion, thus upsetting the balance of myocardial oxygen supply and demand. Conversely, during morphine anaesthesia, stroke volume, cardiac output and stroke work were maintained with lower LVEDP at similar levels of $\mathrm{mVO}_{2}$.

\section{REFERENCES}

I. Ross, J. JR. \& Braunwald, E. The study of left ventricular function in man by increasing resistance to ventricular ejection with angiotensin. Circulation 29: 739 (1964).

2. Sonnenblick, E.H. \& Downing, S.E. Afterload as a primary determinant of ventricular performance. Am. J. Physiol. 204: 604 (1963).

3. Vatner, S.F. \& Smith, N. TY. Effects of halothane on left ventricular function and distribution flow in dogs and primates. Circ. Res. 34: 155 (1974).

4. Deutsch. S., Linde. H.W., Dripps. R.D., el al. Circulatory and respiratory actions of halothane in normal man. Anesthesiology 23: 631 (1962).

5. Shinozaki, T., Mazuzan, J.E. \& Abajlan, J. Jr. Halothane and the heart. Br. J. Anaesth. 40:79 (1968).

6. DUKE, G.S. \& Newhouse, Y.M.G. Micromethod for measuring blood oxygen content by determining oxygen tension after saturation with carbon monoxide. Am. Rev. Respir. Dis. 110:814 (1974).

7. Winer, B.J. Statistical Principles in Experimental Design, 2nd ed., New York, McGraw-Hill, pp. 261-308 (1971).

8. Ross, J. JR. Afterload mismatch and preload reserve: a conceptual framework for the analysis of ventricular function. Prog. Cardiovasc. Dis. 18: 255 (1976).

9. Bugge-ASperheim, B. \& Kill, F. Cardiac mechanisms for regulating stroke volume during elevation of aortic blood pressure in dogs. Scand. J. Clin. Lab. Invest. 30: 23 (1972).

10. Buckburg, G.D., Fixler, D.E., Archie, J.P., et al. Experimental subendocardial ischemia in dogs with normal coronary arteries. Circ. Res. 30:67 (1972).

11. MERIN, R.G. Inhatation anesthetics and myocardial metabolism. Anesthesiology 39: 216(1973).

12. Graham, T.P. JR., Covell, J.W., Sonnenblick, E.H., et al. Control of myocardial oxygen consumption: relative influence of contractile state and tension development. J. Clin. Invest. 47: 375 (1968).

13. Dodge, H.T. The Myocardium: Failure and Infarction. Edited by Braunwald, E., New York, Hospital Practice Publishing Co., pp. 70-78 (1974). 
RÉSUMÉ

L'alteinte de la fonction ventriculaire gauche à la suite d'une augmentation de la post-charge sous anesthésie à l'halothane peut se traduire par une réduction indésirable du volume d'éjection et une augmentation de la consommation d'oxygène au niveau du myocarde, secondaire à l'élévation de la tension intra-murale. Cette possibilité a été étudiée chez six chiens préparés de façon à pouvoir mesurer les pressions systémiques et ventriculaires gauches, le débit sanguin dans l'aorte ascendante et celui de l'artère coronaire descendante antérieure ainsi que le diamètre externe du ventricule gauche. Un cathéter placé dans le sinus coronaire permettait d'y effectuer des prélèvements pour l'analyse des gaz artériels et l'établissement du contenu en oxygène; ces mesures étaient également effectuées au niveau du sang artériel.

Dans un premier temps, on mesurait sous anesthésie à la morphine intra-veineuse ( $4 \mathrm{mg} \cdot \mathrm{kg}^{-1}+0.1 \mathrm{mg} \cdot \mathrm{kg}^{-1}$ aux heures) les pressions systémiques, la fréquence cardiaque, le volume et le travail d'éjection, le débit cardiaque, la pression et le volume externe au niveau du ventricule gauche en fin de diastole ainsi que la consommation d'oxygène myocardique. Les mêmes paramètres ont ensuite été étudiés après avoir ajouté de l'halothane à la concentration de 1.5 pour cent (en fin d'expiration). Les mêmes mesures ont été répétées sous anesthésie à la morphine, de même qu'après addition d'halothane après augmentation de la post-charge au moyen d'une perfusion de phényléphrine jusqu'à élévation de la pression systolique à $23.28 \mathrm{kPa}$ (175 torr)

Nous avons trouvé que l'additon d'halothane abaissait les pressions sytémiques de 52 pour cent. le volume d'éjection de 30 pour cent et la consommation d'oxygène de 46 pour cent par rapport aux valeurs trouvées sous anesthésie à la morphine seule. Des abaissements encore plus marqués, de l'ordre de 20 pour cent pour le volume d'éjection, de 25 pour cent pour le débit cardiaque et de 46 pour cent dans le cas de l'efficacité du myocarde. étaient observés Iorsque l'on augmentait la post-charge de façon significative au moyen de la phényléphrine sous halothane. De même, sous halothanc, $\mathrm{en}$ fin de diastole, les diamètres externes et les pressions ventriculaires s'élevaient de façon significative suite à l'élévation de la post-charge. Une semblable modification de la post-charge produisait peu de changements sous morphine seule. Les consommations d'oxygène myocardique étaient cependant semblables à pressions systémiques égales sous les deux formes d'anesthésie.

Nous concluons qu'une élévation de la post-charge diminue le volume d'éjection et l'efficacité myocardique lorsque l'on ajoute une anesthésie à l'halothane à la morphine intra-veineuse. Par comparaison à une anesthésie à la morphine seule, on observe sous halothane une diminution du débit cardiaque sans augmentation de la consommation d'oxygène à des post-charges semblables. Chez des malades dont la fonction ventriculaire est déjà déficiente. la dépression additionnelle du volume d'éjection par une élévation de la post-charge sous halothane peut s'avérer dommageable. 